\title{
UJI MINIMUM INHIBITORY CONCENTRATION (MIC) EKSTRAK RUMPUT LAUT (Eucheuma cottonii) SEBAGAI ANTIBAKTERI TERHADAP Streptococcus mutans
}

\author{
${ }^{1}$ Heryudi J. J. Soelama \\ ${ }^{2}$ Billy J. Kepel \\ ${ }^{3}$ Krista V. Siagian
}

\author{
${ }^{1}$ Kandidat Skripsi Program Studi Kedokteran Gigi Fakultas Kedokteran \\ ${ }^{2}$ Bagian Kimia Program Studi Kedokteran Umum Fakultas Kedokteran \\ ${ }^{3}$ Program Studi Kedokteran Gigi Fakultas Kedokteran \\ Universitas Sam Ratulangi Manado \\ Email: jovly@myself.com
}

\begin{abstract}
Dental caries is an oral cavity disease which becomes a health problem in Indonesia. Bacteria that play some important role in caries formation are Streptococcus mutans. One of the nature material that can be used to restrain Streptococcus mutans is seaweed Eucheuma cottonii. This study aimed to determine the Minimum Inhibitory Concentration (MIC) of seaweed Eucheuma cottonii extract against Streptococcus mutans. This was an experimental laboratory study with a post test only control group design. MIC test was done by serial dilution, turbidimetry, and spectrophotometry methods, as well as bactericidal test using aa calibration method. Eucheuma cottonii were taken from the sea around Naen island and then were extracted with maceration method using ethanol $96 \%$. The results showed that the MIC of Echeuma cottonii extract was in the concentration of $6.25 \%$ against Streptococcus mutans. Growth inhibition of Streptococcus mutans was significant in the concentration of $6.25 \%, 12.5 \%, 25 \%, 50 \%$, and $100 \%$. MIC of Eucheuma cottonii extract was $6.25 \%$ but the MBC or bactericidal effect was not found.The higher concentration of Eucheuma cottonii used, the greater ability to inhibit the growth of Streptococcus mutans. Conclusion: Seaweed Echeuma cottonii extract has bacteriostatic abilities but do not have bactericide abilities to against Streptococcus mutans.
\end{abstract}

Keywords: streptococcus mutans, mic, eucheuma cottonii, alternative medicine, coastal communities

\begin{abstract}
Abstrak: Karies gigi merupakan penyakit rongga mulut yang paling banyak diderita masyarakat dan menjadi salah satu masalah kesehatan di Indonesia. Bakteri yang paling berperan dalam pembentukan karies adalah Streptococcus mutans. Cara alternatif untuk menanggulangi Streptococcus mutans adalah dengan menggunakan bahan alami yaitu rumput laut (Eucheuma cottonii).Tujuan penelitian ini adalah untuk mengetahui Minimum Inhibitory Concentration (MIC) rumput laut (Eucheuma cottonii) terhadap Streptococcus mutans. Penelitian ini merupakan penelitian eksperimental laboratorium menggunakan desain post-test only control group design. Uji MIC dilakukan dengan metode serial dilusi, turbidimetri dan spektrofotometri, serta uji kalibrasi untuk uji sifat bakteriosid. Sampel diambil dari perairan pulau Naen kemudian diekstraksi dengan metode maserasi menggunakan pelarut etanol 96\%. Hasil penelitian menunjukkan bahwa MIC ekstrak rumput laut (Eucheuma cottonii) pada konsentrasi $6.25 \%$ terhadap Streptococcus mutans. Hasil analisis dan pengolahan data menunjukkan daya hambat ekstrak rumput laut (Eucheuma cottonii) terhadap pertumbuhan Streptococcus mutans yang paling signifikan ialah konsentrasi 6,25\%, 12,5\%, 25\%, 50\%, dan 100\%. MIC ekstrak rumput laut (Eucheuma cottonii) 6,25\% sedangkan MBC atau sifat
\end{abstract}


bakteriosid tidak ditemukan. Semakin tinggi konsentrasi ekstrak rumput laut (Eucheuma cottonii) yang digunakan, maka semakin besar kemampuan menghambat pertumbuhan Streptococcus mutans. Simpulan: Ekstrak rumput laut (Eucheuma cottonii) memiliki sifat bakteriostatik namun tidak memiliki sifat bakteriosid terhadap Streptococcus mutans.

Kata kunci: streptococcus mutans, mic, eucheuma cottonii, pengobatan alternatif, masyarakat pesisir pantai

Sumber daya kelautan berperan penting dalam mendukung pembangunan ekonomi daerah dan nasional. Sumber daya kelautan tersebut mempunyai keunggulan komparatif karena tersedia dalam jumlah yang besar dan beraneka ragam serta dapat dimanfaatkan dengan biaya eksploitasi yang relatif murah sehingga mampu menciptakan kapasitas penawaran yang kompetitif. ${ }^{1}$ Rumput laut merupakan salah satu sumber daya kelautan negara dan sumber pendapatan bagi masyarakat pesisir. $^{2}$

Rumput laut mengandung komponenkomponen metabolit penting yang dapat dimanfaatkan oleh tubuh. Komponenkomponen rumput laut terdiri dari dua kelompok yaitu primer dan sekunder. Komponen primer berupa vitamin, mineral, serat, alginat, dan agar, sedangkan komponen metabolit sekunder dari rumput laut berpotensi sebagai produser metabolit bioaktif yang beragam dengan aktivasi yang sangat luas sebagai antibakteri, antivirus, antijamur, dan sitotastik. ${ }^{3}$ Menurut Dr Nick Jakubovics dari sekolah ilmu gigi di Newcastle University, komponen rumput laut bisa mengendalikan bakteri seperti Streptococcus mutans yang menyebabkan kerusakan gigi. ${ }^{4}$ Salah satu kerusakan gigi adalah karies gigi dan faktor penyebab terjadinya karies gigi akibat peran dari bakteri yang terdapat pada Streptococcus mutans. ${ }^{5}$ Streptococcus mutans merupakan bakteri penyebab awal terjadinya karies gigi karena adanya variasi faktor-faktor virulensi yang khas pada bakteri yang telah diisolasi. Streptococcus mutans termasuk bakteri gram positif yang dapat memetabolisme karbohidrat terutama sukrosa dan menciptakan suasana asam di rongga mulut. ${ }^{6}$

Penelitian sebelumnya mengenai efektifitas rumput laut jenis Eucheuma cottonii sebagai antibakteri terhadap bakteri Streptococcus mutansnamun belum diteliti mengenai minimum inhibitory concentration (MIC). ${ }^{7}$ Minimum inhibitory concentration (MIC) adalah konsentrasi minimum sebagai antimikroba yang dapat menghambat mikroorganisme sesudah 18 sampai dengan 24 jam setelah masa inkubasi. ${ }^{8}$ Penelitian ini bertujuan untuk mengetahui MIC dari ekstrak rumput laut (Eucheuma cottonii) terhadap Streptococcus mutans.

\section{BAHAN DAN METODE PENELITIAN}

Penelitian ini merupakan penelitian eksperimental laboratorium, menggunakan rancangan eksperimen murni (true experimental design) dengan rancangan penelitian post test only control group design.Subjek dalam penelitian ini adalah koloni bakteri Streptococcus mutans yang diperoleh dari sediaan Laboratorium Mikrobiologi Fakultas Kedokteran Universitas Sam Ratulangi. Ekstrak rumput laut (Eucheuma cottonii) didapat dengan cara ekstraksi dengan metode maserasi. Pembuatan ekstrak rumput laut (Eucheuma cottonii) dilakukan di Laboratorium kimia dan bahan hayatiFakultas Perikanan dan Ilmu Kelautan Universitas Sam Ratulangi Manado.

Sampel diperoleh dari Pulau Nain. Sampel kemudian dicuci, kemudian diangin-anginkan selama \pm 3 hari dan tidak boleh terkena sinar matahari langsung. Sampel rumput laut kemudian dipotongpotong dan ditimbang sebanyak 200 gram, kemudian di masukan ke dalam wadah toplesdan ditambahkan etanol 96\% sebanyak 1000 ml, kemudiandimaserasi selama 24 jam pada suhu kamar. Setelah 24 jam, larutan difiltrasi atau dipisahkan 
dengan menggunakan penyaring Buchner. Residu penyaringan diangin-anginkan dan dilakukan maserasi ulang sampai 3 kali. Hasil saringan 1-3 dicampur dan dipekatkan dengan Rotary Vacum Evaporator dengan suhu $40^{\circ} \mathrm{C}$ sampai didapatkan ekstrak pekat.

Untuk mendapatkan berbagai konsentrasi, digunakan metode serial dilusi atau pengenceran bertingkat dengan perbandingan 1:2(w/v). Metode pengujian yang digunakan adalah metode turbidimetri dan kemudian diuji lebih akurat dengan metode spektrofotometri, kemudian diuji sifat bakteriostatik dan bakteriosid dengan uji TPC (Total Plate Count).

Sediaan bakteri Streptococcus mutans yang disimpan di media agar diambil dengan jarum ose steril, lalu ditanamkan pada media agar miring dengan cara menggores. Bakteri yang telah digores pada media agar diinkubasi dalam inkubator pada suhu $37^{0} \mathrm{C}$ selama 1 x 24 jam. Bakteri yang telah diinkubasi diambil koloninya dari media agar miring dengan menggunakan jarum ose steril kemudian dimasukkan ke dalam BHI-B sampai kekeruhannya sama dengan standar McFarland 1.Kemudian sebanyak 11 tabung reaksi steril disiapkan. Setiap tabung uji diberi label 1-9, kemudian tabung 10 diberi label $\mathrm{K}(+)$ yang merupakan kontrol positif, yaitu tabung yang berisi suspensi bakteri setara denganstandar kekeruhan McFarland 1 . Tabung 11 diberi label K(-) yang merupakan kontrol negatif, yaitu tabung berisi ekstrak rumput laut (Eucheuma cottonii) dengan konsentrasi $100 \%$. Tabung 1 diisi sebanyak $4 \mathrm{ml}$ konsentrasi 100\% ekstrak rumput laut(Eucheuma cottonii). Tabung 2-9 diisi dengan $2 \mathrm{ml}$ media cair BHI-B. Kemudian ambil 2 ml larutan dari tabung 1, dimasukkan ke dalam tabung 2, dicampur hingga homogen sehingga didapat konsentrasi 50\%. Hal yang sama dilakukan hingga tabung 9 hingga didapatkan semua konsentrasi ekstrak denganperbandingan 1:2(w/v).

Untuk menguji kekeruhan, diambil media suspensi bakteri yang sudah disetarakan dengan standar kekeruhan McFarland 1 sebanyak $1 \mathrm{ml}$ dimasukkan ke dalam tabung reaksi perlakuan label 1-9. Kemudian semua tabung dimasukkan ke dalam anaerobic jar kemudian diinkubasi pada suhu $37^{0} \mathrm{C}$ selama 1 x 24 jam dengan 3 kali pengulangan inkubasi.Setiap sesudah 1 kali inkubasi diamati dengan metode turbidimetri atau pengamatan kekeruhan. Apabila kekeruhan tabung masih setara atau lebih keruh dari tabung $\mathrm{K}(+)$ yang berisi suspensi bakteri McFarland 1 berarti bakteri masih dapat tumbuh dengan subur, namun ketika larutan dalam tabung terlihat mulai lebih jernih daripada tabung $K(+)$ berarti pertumbuhan bakteri mulai terhambat, hal inilah yang menunjukkan Minimum Inhibitory Concentration (MIC).

Setelah pengamatan turbidimetri pada inkubasi ke-3 kemudian dilakukan pengujian dengan metode spektrofotometriyang lebih akurat dalam menentukan kekeruhan dengan cara mengukur panjang gelombang serta nilai absorbansi kekeruhan yang ada pada setiap tabung perlakuan. Setelah uji spektrofotometri dilakukan uji TPC untuk mengetahui sifat bakteriostatik dan bakteriosid.Uji TPC dilakukan pada media PCA (Plate Count Agar) yang berisi konsentrasi ekstrak dari tabung yang terlihat paling jernih, dibuat 3 kali perlakuan atau 3 cawan petri. Kemudiantiap cawan petri diinkubasi pada suhu $37^{\circ} \mathrm{C}$ selama $1 \times 24$ jam. Koloni dihitung dengan menggunakan colony counter.

\section{HASIL PENELITIAN}

Hasil pengujian turbidimetri 3 kali inkubasi didapatkan hasil bahwa pada tabung konsentrasi $12,5 \%$ (Nomor 4) terlihat lebih jernih dibandingkan tabung nomor 5-9. (Gambar 1). Data yang ada kemudian dimasukkan ke dalam tabel.

Pengukuran metode spektrofotometri untuk mengukur tingkat kekeruhan suatu suspensi bakteri secara akurat. Diukur pada panjang gelombang 400 - $800 \mathrm{~nm}$ sesuai dengan panjang gelombang sinar tampak. 
Soelama, Kepel, Siagian: Uji minimum inhibitory...

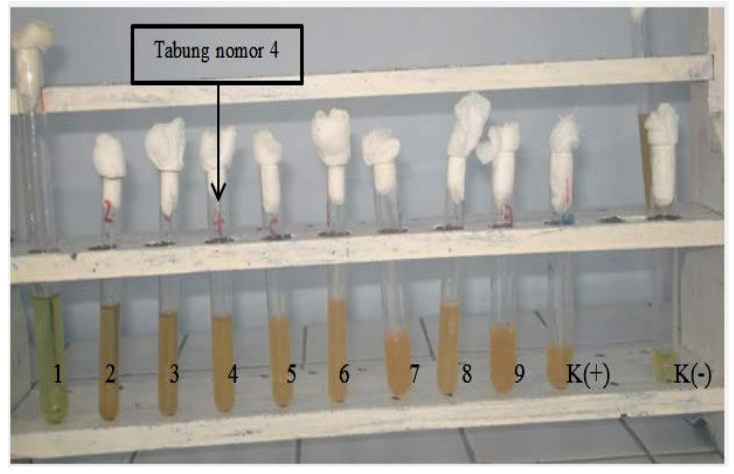

Gambar 1. Uji MIC ekstrak rumput laut (Eucheuma cottonii) terhadap Streptococcus mutans (inkubasi ke-1) metode turbidimetri

Pengujian sifat bakteriostatik dan bakteriosid ekstrak rumput laut (Eucheuma cottonii) terhadap Streptococcus mutans dilakukan menggunakan metode uji kalibrasi, dengan cara menghitung bintikbintik putih yang terlihat pada kaca Petri (Gambar 2).

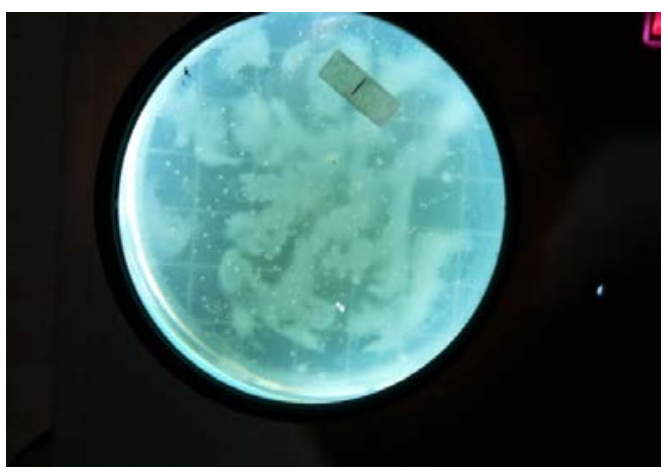

Gambar 2. Hasil uji kalibrasi ekstrak rumput laut (Eucheuma cottonii) terhadap Streptococcus mutans (Perlakuan ke-1). Tampak 119 koloni berupa bintik-bintik putih.

\section{BAHASAN}

Setelah 3 kali diinkubasi pengamatan dilakukan dengan pengamatan turbidimetri atau pengamatan kekeruhan secara visual. Inkubasi 1, 2, dan 3 menunjukkan hasil yang sama yaitu hasil pengamatan turbidimetri MIC ekstrak rumput laut (Eucheuma cottonii) terhadap Streptococcus mutans terdapat pada tabung nomor 4 dengan konsentrasi 12,5\% yang ditunjukkan secara visual dimana tabung nomor 4 lebih jernih dari tabung $\mathrm{K}\left({ }^{+}\right)$ yang berisi suspensi bakteri setara $M c$ Farland 1 dan data yang ada diolah kemudian ditampilkan dalam Tabel 1.

Tabel 1. Hasil uji MIC ekstrak rumput laut (Eucheuma cottonii) terhadap Streptococcus mutans

\begin{tabular}{cccc}
\hline Konsentrasi & \multicolumn{3}{c}{ Hasil } \\
Ekstrak & \multicolumn{3}{c}{} \\
Rumput & & & \\
Laut & Inkubasi & Inkubasi & Inkubasi \\
$\begin{array}{c}\text { (Eucheuma } \\
\text { cottonii) }\end{array}$ & 1 & 2 & 3 \\
\hline $0,39 \%$ & + & + & + \\
$0,78 \%$ & + & + & + \\
$1,56 \%$ & + & + & + \\
$3,125 \%$ & + & + & + \\
$6,25 \%$ & + & + & + \\
$12,5 \%$ & - & - & - \\
$25 \%$ & - & - & - \\
$50 \%$ & - & - & - \\
$100 \%$ & - & - & - \\
$\mathrm{K}(+)$ & + & + & + \\
$\mathrm{K}(-)$ & - & - & - \\
\hline
\end{tabular}

Keterangan: Tanda $(+)$ : cairan terlihat keruh, artinya bakteri masih tumbuh. Tanda (-): cairan di dalam tabung mulai berkurang kekeruhannya, yang artinya pertumbuhan Streptococcus mutans mulai terhambat. $\mathrm{K}(+)$ : kontrol positif yang berisi suspensi bakteri setara McFarland 1. K(-): kontrol negatif yang berisi ekstrak 100\%.

Tabel 2 menunjukkan hasil pengukuran dengan alat spektrofotometer didapatkan hasil MIC yang berbeda dengan metode turbidimetri. Jika secara turbidimetri, MIC terlihat pada tabung nomor 4 dengan konsentrasi 12,5\%, pada hasil pengukuran spektrofotometri, nilai MIC terdapat pada tabung nomor 5 dengan konsentrasi 6,25\%.

Hal ini ditunjukkan dengan nilai absorbansi pada tabung nomor 5 dengan konsentrasi $6,25 \%$ yaitu 1,690, yang lebih kecil dari nilai absorbansi standar $M c$ Farland 1 yaitu 1,711 sedangkan tabung nomor 6 dengan nilai absorbansi yaitu 2,203 telah melewati standar Mc Farland 1 (Tabel 2). Hasil ini menunjukkan bahwa pada tabung nomor 5 dengan konsentrasi $6,25 \%$ telah terjadi penghambatan pertumbuhan Streptococcus mutans. 
Tabel 2. Hasil uji spektrofotometri MIC ekstrak rumput laut (Eucheuma cottonii) terhadap Streptococcus mutans

\begin{tabular}{cccc}
\hline \multicolumn{4}{c}{ Rentang Panjang Gelombang $400-800 \mathrm{~nm}$} \\
\hline No & Konsentras & P.Gelomban & Absorbans \\
1 & $100 \%$ & 664,50 & 0,325 \\
2 & $50 \%$ & 667,50 & 1,036 \\
3 & $25 \%$ & 489,50 & 1,075 \\
4 & $12,5 \%$ & 606,50 & 1,132 \\
5 & $6,25 \%$ & 603,00 & 1,690 \\
6 & $3,125 \%$ & 604,50 & 2,203 \\
7 & $1,56 \%$ & 601,00 & 2,309 \\
8 & $0,78 \%$ & 553,00 & 2,329 \\
9 & $0,39 \%$ & 561,00 & 2,359 \\
10. & $M c$ & 204,50 & 1,711 \\
\hline
\end{tabular}

Hal ini sesuai dengan pendapat Mentari (2012), bahwa dalam penentuan absorbansi larutan jika suatu larutan terlalu pekat maka akan diperoleh nilai absorbansi yang lebih tinggi karena ada banyak molekul yang berinteraksi dengan sinar. Akan tetapi dalam larutan yang lebih encer sulit untuk melihat warnanya, karena nilai absorbansinya lebih rendah. ${ }^{9}$

Berdasarkan pengamatan turbidimetri dan spektrofotometri, ekstrak rumput laut (Eucheuma cottonii) konsentrasi 100\% memiliki hasil yang paling signifikan dimana secara visual tampak jernih dan berdasarkan spektrofotometri konsentrasi 100\% memiliki nilai absorbansi yang paling baik, yaitu mendekati nol. Oleh karena itu dilakukan uji kalibrasi penghitungan jumlah bakteri TPC (Total Plate Count) untuk mengetahui ada atau tidaknya pertumbuhan bakteri. ${ }^{10}$ Gambar 4,5,6 menunjukkan hasil uji TPC, didapatkan hasil119-162 koloni sehingga dinyatakan bahwa bakteri masih dapat tumbuh dan tidak terdapat sifat bakteriosid pada ekstrak rumput laut (Eucheuma cottonii) terhadap Streptococcus mutans.

Banyak penelitian menunjukan bahwa dalam tumbuhan rumput laut (Eucheuma cottonii) terkandung senyawa aktif yang meliputi flavonoid, fenol, dan tanin. Senyawa-senyawa ini dilaporkan memiliki daya hambat terhadap mikroorganisme patogen. ${ }^{11}$ Flavonoid mengandung suatu senyawa fenol. Pada konsentrasi tinggi fenol berkoagulasi dengan protein seluler. Aktifitas ini sangat efektif ketika bakteri dalam tahap pembelahan, yaitu saat lapisan fosfolipid di sekeliling sel sangat tipis, sehingga fenol dengan mudah berpenetrasi merusak dinding sel dan menyebabkan kematian sel. $^{12}$

Ekstrak rumput laut (Eucheuma cottonii) hanya bersifat bakteriostatik karena hanya mampu menghambat pertumbuhan bakteri Streptococcus mutans. Suatu antimikroba bersifat bakteriostatik jika senyawa antimikroba tersebut hanya mampu menghambat pertumbuhan bakteri ketika pemberian senyawa terus dilakukan namun jika dihentikan atau habis, maka pertumbuhan dari bakteri akan kembali meningkat yang ditandai dengan masih adanya pertumbuhan koloni bakteri. Sebaliknya bersifat bakteriosid jika kejernihan meningkat pada masa inkubasi berikutnya, hal ini dikarenakan senyawa tersebut mampu membunuh dan menghentikan aktivitas fisiologis dari bakteri, meskipun pemberian senyawa tersebut dihentikan. ${ }^{13}$

Berdasarkan penelitian ini ditemukan bahwa Minimum Inhibitory Concentration (MIC) ekstrak rumput laut (Eucheuma cottonii) terhadap Streptococcus mutans dengan metode turbidimetri adalah pada konsentrasi 12,5\% sedangkan dengan metode spektrofotometri adalah pada konsentrasi 6,25\%. Nilai MIC yang menjadi hasil dari penelitian ini adalah nilai yang berdasarkan metode yang lebih akurat yaitu metode spektrofotometri dimana MIC terdapat pada konsentrasi 6,25\%. Spektrofotometri merupakan penelitian yang terinci mengenai penyerapan energi kimia oleh spesi kimia, memungkinkan kecermatan yang lebih besar dalam perincian dan pengukuran kualitatif. ${ }^{14}$

\section{SIMPULAN}

Berdasarkan hasil penelitian yang dilakukan dapat disimpulkan bahwa:

1. Minimum Inhibitory Concentration (MIC) ekstrak rumput laut (Eucheuma cottonii) terhadap Streptococcus 
mutans pada konsentrasi 6,25\%.

2. Semakin tinggi konsentrasi ekstrak rumput laut (Eucheuma cottonii) yang digunakan maka semakin besar kemampuan dalam menghambat pertumbuhan Streptococcus mutans.

3. Ekstrak rumput laut (Eucheuma cottonii) hanya memiliki sifat bakteriostatik terhadap Streptococcus mutans dan tidak memiliki sifat bakteriosid terhadap Streptococcus mutans.

\section{SARAN}

1. Dilakukan penelitian lebih lanjut mengenai pembuatan obat dengan bahan dasar rumput laut (Eucheuma cottonii) berdasarkan nilai MIC.

2. Dilakukan penelitian ekstrak rumput laut (Eucheuma cottonii) dengan bakteri uji lainnya yang berasal dari rongga mulut.

3. Dilakukan pembuatan larutan standar kekeruhan Mc Farland dengan bantuan nephelometer agar diperoleh kepadatan bakteri uji yang lebih akurat.

\section{DAFTAR PUSTAKA}

1. Syafikri D. Prospek budidaya rumput laut dalam mendukung pembangunan ekonomi berbasis kelautan di Kabupaten Sumbawa. Manajemen Perencanaan dan Pengelolaan Sumber daya Kelautan.Program Pasca Sarjana. [Tesis]. Semarang: Program Pascasarjana Universitas Diponegoro, 2009.

2. Bawa AA, Bawa P, Ida Ratu L. Penentuan $\mathrm{pH}$ optimum isolasi karaginan dari rumput laut jenis (Eucheuma cottonii). Jurnal kimia. 2007;1(1):1520.

3. Siregar AF, Sabdono A, Pringgenies D. Potensi antibakteri ekstrak rumput laut terhadap bakteri penyakit kulit Pseudomonas Aeruginosa, Staphylococus Epidermis dan Micrococus Luteus. Journal of marine research. 2012;1(2):152.

4. Kelompok studi rumput laut Universitas Diponegoro. Mikroba rumput laut bisa hentikan kerusakan gigi. 2013.
Tersediadalam:http://seaweed.undip.a c.id/mikroba-rumput-laut-bisa hentikan-kerusakan-gigi/. Diakses 20 maret 2015.

5. Bahar A. Paradigma Baru Pencegahan Karies Gigi. Jakarta: Fakultas Ekonomi Universitas Indonesia,. 2011.

6. Alfath CR, Yulina V, Sunnati. Antibacterial effect of granati fructus cortex extract on Streptococcus mutans in vitro. Journal of dentistryIndonesia. 2013;20 (1):5.

7. Yuliastuti E. Efektivitas antibakteri rumput laut (Eucheuma cottonii) terhadap bakteri penyebab karies Streptococcus Mutans [Skripsi]. Manado: Unsrat, 2014.

8. Golan DE, Wilkins WL. Principles of Pharmacology: The Pathophysiologic Basis of Drug Therapy (3rd ed.). LWW, 2008; p.720.

9. Mentari, Rahayu S. Absorbansi. Tersedia dalam:http://www.scribd.com/doc/95 126973/ m. Makassar. 2012. Diakses 12 Juli 2015.

10. Mardiani I. Daya antibakteri ekstrak rumput laut (Eucheuma cottonii) terhadap pertumbuhan bakteri vibrio harveyi dengan metode dilusi secara in vitro. Jurnal fakultas perikanan dan kelautan. Surabaya: Unair, 2010.

11. Fankhauser BD. Pour plate technique for bacterial enumeration. University of Cincinnati Clermont College. Batavia OH 45103.2002. [cited 2015 July 12]. Available from: http: //biology.clc.uc.edu/fankhauser/Labs/ Microbiology/Meat_Milk/Pour_Plate. htm.

12. Calvin J, Antimicrobial activity of raisin's infusum againts the growth of Streptococcus mutans, in vitro [Skripsi]. Jakarta: Fakultas Kedokteran Gigi UI, 2008.

13. Dwyana Z, Johannes E, Sareong W. Jurnal uji ekstrak kasar alga merah Eucheuma cottonii sebagai antibakteri terhadap bakteri patogen. Makasssar: FMIPA Unhas, 2011.

14. Hendayana S, Kadarohman A, Sumarna A, Supriatna A. Kimia Analitik Instrumen (Edisi 1). Semarang: IKIP Press, 1994. 